\title{
Vacutainer Serum Separator Sebagai Alternatif Penampung Darah Pada Pemeriksaan Kadar Ureum
}

\author{
Budi Setiawan $^{1,2}$, Ulfah Restu Nugraheni ${ }^{3^{*}}$, Muji Rahayu ${ }^{4}$ \\ 1) Sarjana Terapan Teknologi Laboratorium Medik, Poltekkes Kemenkes Yogyakarta, Indonesia \\ ${ }^{2)}$ Pusat Unggulan Iptek Inovasi Teknologi Kesehatan Masyarakat, Poltekkes Kemenkes \\ Yogyakarta, Indonesia \\ ${ }^{3)}$ Puskesmas Ayah 1, Kebumen, Jawa Tengah, Indonesia \\ ${ }^{4)}$ D-III Teknologi Laboratorium Medik, Poltekkes Kemenkes Yogyakarta, Indonesia \\ *Correspondence author: ulfahrenugraheni@gmail.com
}

Tanggal Submit:

11 Februari 2021

Tanggal Review:

22 Februari 2021

Tanggal Publish

Online: 18 Juni 2021

\section{ABSTRACT}

Serum using is preferred for urea level because it does not use anticoagulants which can interfere with activity and reaction to the results. The tubes that are widely used to collect blood into serum are vacutainer serum separator and vacutainer plain.This researche aims to determine the degree of agreement $\mathrm{s}$ between vacutainer serum separator and vacutainer plain usage on serum urea level result.This research was cross sectional design and hold on October 2020 with subject were taken from thirty blood samples of health analyst students which taken randomly and had no history of disease or kidney function disorder. Each student was taken $6 \mathrm{ml}$ of blood drawn using a venoject with each vacutainer containing $3 \mathrm{ml}$, so we had 60 data. The data were analyzed by descriptively and inferentially using the Interclass Correlation Coefficient (ICC) statistical test. From the descriptive analysis, the difference in mean levels was $0.35 \mathrm{mg} / \mathrm{dL}$ and the ICC statistical test resulted in a degree of agreement 0.745 . The data were analyzed by descriptively and inferentially using the Interclass Correlation Coefficient (ICC) statistical test. From the descriptive analysis, the difference in mean levels was $0.35 \mathrm{mg} / \mathrm{dL}$ and the ICC statistical test resulted in a degree of agreement was 0.745 . The calculation of the average working time between the vacutainer serum separator and the vacutainer plain was 4 minutes 38 seconds and 35 minutes 58 seconds. The analysis concluded that the vacutainer serum separator and the vacutainer plain could be used as an alternative of blood collecting tubes for urea level testing which proved to be no significant difference in the results from this research.

Keywords : Urea level, Vacutainer Serum Separator, Vacutainer Plain

\section{PENDAHULUAN}

Penggunaan serum lebih serum tidak menggunakan antikoagulan diutamakan dalam pemeriksaan klinis daripada plasma, hal ini dikarenakan yang ditambahkan sehingga komponenkomponen yang terkandung didalam 
serum tidak terganggu dalam hal aktifitas dan reaksinya terhadap hasil (Nursalam, 2016).

Penggunaan sampel serum dimaksudkan untuk menghindari adanya pengaruh antikoagulan terhadap pemeriksaan. Untuk mendapatkan serum dibutuhkan wadah penampung darah yang disebut dengan tabung vakum. Di dalam tabung vakum biasanya ditambahkan zat aditif yang memiliki satu atau lebih fungsi spesifik untuk tujuan pemeriksaan tertentu (Verdiansah, 2016).

Produsen telah memproduksi berbagai tabung yang menyajikan pemisahan berkualitas tinggi antara serum atau plasma dan sel untuk mengurangi TAT dan mengurangi cellular intent (Kösem et al., 2020).

Tabung penampung darah memiliki beberapa keterbatasan. Keterbatasan ini termasuk kinerja yang tidak tepat dalam penyimpanan sampel darah yang lama dan kesulitan untuk pemisahan serum darah dari sel darah merah yang sesuai. Selain itu, kontak yang lama antara serum dan sel darah dapat mengubah warna serum dari kuning ke merah(Li et al., 2010). Untuk mengatasi masalah ini, diperkenalkan vacutainer serum separatot (SST) yang mengandung silika dan gel polimer untuk pemisahan serum. Gel pemisah serum yang terletak di ujung tabung berperan sebagai penghalang kimiawi dan fisik yang stabil antara serum dan darah beku (Bush, 2012).

Gel pemisah serum darah secara signifikan meningkatkan stabilitas serum, memberikan kemudahan dalam penyimpanan dan pengangkutan(Babakhani et al., 2018). Faktor terpenting yang mempengaruhi posisi gel pemisah serum dalam tabung pengumpulan darah adalah viskositas dan kepadatan gel, kecepatan sentrifugasi, suhu, dan kondisi penyimpanan(Lindh et al., 2013).

Namun, gel pemisah komersial yang banyak tersedia, harganya mahal dan memiliki beberapa batasan kinerja, ketidakstabilan untuk analit tertentu, ketidakstabilan gel polimer dalam kondisi suhu ekstrim, adanya bagian gel atau lapisan berminyak dalam serum, penyerapan zat tertentu dan beberapa hormon steroid ke dalam gel (Bush, 2012).

Penelitian ini untuk mengetahui derajat kesesuaian hasil kadar ureum serum pada penggunaan vacutainer serum separator dan vacutainer plain sehingga dapat ditentukan vacutainer yang terbaik yang dapat digunakan.

\section{METODE PENELITIAN}

Penelitian ini merupakan penelitian observational analitik dengan desain penelitian cross sectional. 
Penelitian dilaksanakan pada bulan

Oktober 2020 di Laboratorium Kimia

Klinik Jurusan Analis Kesehatan

Poltekkes Kemenkes Yogyakarta.

Penelitian ini menggunakan sampel darah mahasiswa yang diambil secara acak dengan kriteria mempunyai kadar ureum $10-50 \mathrm{mg} / \mathrm{dl}$, dan tidak memiliki riwayat penyakit ginjal. Jumlah sampel ditetapkan sebesar 30 sampel dengan interval kepercayaan $90 \%$ dan nilai $\alpha=$ 0,05 . Penelitian dilakukan dengan mengambil sampel darah sebanyak masing-masing $3 \mathrm{ml}$ pada vacutainer serum separator dan vacutainer plain. Pembuatan periode pendahuluan terlebih dahulu dilakukan sebelum penelitian dilaksanakan dengan melakukan pengukuran terhadapserum kontrol sebanyak 20 kali. Kemudian di evaluasi dengan grafik Levey-Jenings dan aturan Westgard.

Diperoleh sebanyak 60 data, kemudian dianalisis secara deskriptif dan inferensial menggunakan uji Interclass Correlation Coefficient (ICC) dengan program SPSS 16.00 for windows. Dari data deskriptif menggambarkan rerata variabel terikat, standar deviasi, nilai maksimum dan nilai minimum. Hasil dari analisis ICC adalah derajat kesesuaian berdasarkan nilai koefisien korelasi.

\section{HASIL}

Selama pelaksanaan penelitian, hasil Quality Control (QC) dapat diterima karena nilai kontrol tidak ada yang melanggar aturan westgard (terlampir). Pengukuran kadar ureum ureum pada penggunaan vacutainer serum separator dan vacutainer plain, diperoleh hasil sebagai berikut :

\begin{tabular}{ccc} 
Tabel 1. Data Hasil Pemeriksaan Kadar & $\begin{array}{c}\text { Ureum } \\
\text { Vacutainer } \\
\text { Serum } \\
\text { Separator }\end{array}$ & $\begin{array}{c}\text { Vacutainer } \\
\text { Plain }\end{array}$ \\
\hline Rerata & 46,51 & 46,16 \\
\hline $\begin{array}{c}\text { Standar } \\
\text { Deviasi }\end{array}$ & 49,35 & 1,36 \\
\hline $\begin{array}{c}\text { Nilai } \\
\text { Maksimum }\end{array}$ & 49,35 & 48,45 \\
& & \\
\hline $\begin{array}{c}\text { Nilai } \\
\text { Minimum }\end{array}$ & 43,96 & 43,79 \\
\hline Selisih Rerata & \multicolumn{3}{c}{0,35} \\
\hline ANOVA & 0,069 \\
\hline ICC & 0,745 \\
\hline
\end{tabular}

Tabel 1. menunjukkan bahwa terdapat selisih kadar ureum antara penggunaan dua tabung, tetapi nilai tersebut relatif kecil yakni $0,35 \mathrm{mg} / \mathrm{dL}$ dan tidak memberikan makna klinis sehingga tidak terlihat perbedaan yang signifikan. Berdasarkan analisis ANOVA menunjukkan tidak ada perbedaan dengan nilai sig 0,069 ( $p>0,05)$, sedangkan untuk nilai output ICC yang dihubungkan dengan reliabilitas Alpha 0,854 didapat sebesar 0,745 yang berarti kesesuaian antara penggunaan vacutainer serum separator dan vacutainer plain ditingkat sedang. Nilai koefisien korelasi yang didapatkan 
bisa lebih tinggi tergantung dengan interval kepercayaan dan nilai $\alpha$.

\section{PEMBAHASAN}

Pemeriksaan kontrol dilakukan terlebih dahulu sebelum melakukan pemeriksaan penelitian. Pemeriksaan kontrol serum merupakan pengawasan sistematis periodik terhadap alat, metode, dan reagen yang dilakukan untuk memantau ketepatan suatu pemeriksaan di laboratorium (Sukorini, 2010).

Penggunaan SST mempunyai kelebihan bila dibandingkan dengan tabung vakum plain yaitu waktu yang dibutuhkan untuk mendapatkan serum lebih singkat. Selain itu, SST dapat mencegah terjadinya pencampuran kembali antara serum dan sel darah merah yang terlah terpisah. Gel pemisah digunakan untuk memisahkan serum dari penggumpalan darah utuh atau plasma dari sel. Dalam hal ini, tabung pemisah serum (SST) mudah digunakan, memerlukan waktu pemrosesan yang singkat, menghasilkan tingkat serum yang lebih tinggi, membatasi aerosolisasi berbahaya, hanya membutuhkan satu langkah sentrifugasi.

Selain itu, SST dapat mencegah terjadinya pencampuran kembali antara serum dan sel darah merah yang terlah terpisah (Bowen and Remaley, 2014).
Vacutainer serum separator adalah tabung vakum yang berisi aktivator pembekuan berisi gel yang dapat memisahkan serum dan darah biasa, sedangkan vacutainer plain adalah tabung vakum tanpa antikoagulan dan tidak berisi gel pemisah. Penggunaan vacutainer serum separator mempunyai kelebihan bila dibandingkan dengan tabung vakum plain yaitu waktu yang dibutuhkan untuk mendapatkan serum lebih singkat dengan adanya micronizet silica dan polymer gel innert sebagai pemisah serum, sehingga diperoleh kualitas serum yang bagus, dan mengurangi resiko timbulnya fibrin yang dapat menyumbat alat (Cuhadar et al., 2012).

Penggunaan vacutainer serum separator dan vacutainer plain dapat dijadikan alternatif untuk pemeriksaan kimia darah ini didukung oleh berbagai penelitian, tetapi hasil dimungkinkan akan berbeda, jika pasien adalah pasien hemodialisis. Pada pasien gagal ginjal yang mendapatkan terapi antikoagulan, penggunaan sampel serum memberikan tantangan tersendiri. Pemberian antikoagulan tersebut membuat sampel dari pasien gagal ginjal kronis membutuhkan waktu yang lama untuk membeku sepenuhnya. pembentukan fibrin, yang memiliki potensi untuk mengganggu hasil tes, dapat disebabkan oleh pembekuan laten dalam sampel 
yang dikumpulkan dari pasien menggunakan antikoagulan (Arslan et al., 2017).

Pengamatan total waktu pengerjaan sampel yang ditampung vacutainer serum separator lebih cepat yakni rata-rata 25 menit. Sedangkan pada penggunaan tabung penampung darah vacutainer plain membutuhkan waktu rata-rata 1 jam 8 menit. Waktu tersebut dipengaruhi karena vacutainer plain membutuhkan tambahan waktu untuk clotting sempurna rata-rata selama 35 menit 50 detik, sedangkan vacutainer serum separator hanya rata-rata sekitar 4 menit 38 detik. Penghitungan waktu ini bisa berbeda jika pengerjaan dilakukan di tempat lain dengan suhu ruang serta ukuran tabung dan volume darah yang berbeda. Hal ini sesuai dengan penelitian yang menunjukkan bahwa penggunaan gel lebih menguntungkan teknisi laboratorium karena tidak mengurangi Turn Around Time (TAT), dan adanya penghalang yang dapat mengurangi pemindahan sampel ke tabung sekunder dan meminimalisir penyebaran aerosol yang berpotensi bahaya. Keuntungan lainnya adalah dapat meningkatkan stabilitas analit dan mengurangi tingkat hemolisis saat pemisahan (Narayanan, 2000).

Adanya beberapa keuntungan tersebut dapat menjadi masukan untuk laboratorium klinis di Indonesia yang saat ini masih menjadikan serum sebagai pilihan utama dalam pemeriksaan kimia darah.

Penelitian tentang penggunaan vacutainer serum separator ini juga sesuai dengan penelitian yang dilakukan oleh (Wei et al., 2010) yang juga menunjukan tidak terjadi perbedaan secara statistik (Two-Ways ANOVA) pada kadar ureum dengan penggunaan tiga jenis tabung (Serum Separator Tube, Vacutainer Lithium Heparin dan Plasma Separator Tube). Berdasarkan hasil tersebut, ketiga tabung dapat dijadikan sebagai pengganti serum untuk pemeriksaan kimia darah (Wei et al., 2010)

Sedangkan penelitian oleh (Fatma, Martsiningsih and Suryanta, 2019), penggunaan vacutainer plain untuk sampel pasien hemodialisa dengan menggunakan Plasma Separator Tube (PST), dan Vacutainer Lithium Heparin menunjukkan bahwa terdapat persentase selisih antar tabung, tetapi nilai tersebut relatif kecil dan tidak memberikan makna klinis sehingga tidak terlihat perbedaan yang signifikan. Persentase selisih kadar ureum antara tabung Vacutainer Li-Heparin dengan Vacutainer Plain memiliki selisih tertinggi, Sedangkan persentase selisih kadar ureum antara Separator Tube dengan Vacutainer Li-Heparin dan antara Separator Tube dengan 
Vacutainer Plain memiliki persentase selisih sebesar 3,15\% dan 2,80\%.

Kelemahan dari penelitian ini adalah penentuan derajat kesesuaian sedang yang menjadi hipotesis peneliti, dimana peneliti mempertahankan interval kepercayaan $90 \%$ dengan mempertimbangkan jumlah sampel yang mampu didapatkan. Dalam analisis ICC penghitungan sampel disesuaikan dengan derajat kesesuaian hipotesis dimana terdapat dua pilihan interval kepercayaan antara $80 \%$ atau $90 \%$. Semakin tinggi interval kepercayaan yang dipilih maka data yang dihasilkan semakin dapat dipercaya. Kemudian menentukan besar sampel yang diperlukan untuk memperkirakan nilai ICC. Dalam penelitian ini subjek sampel dan kriteria sampel terlalu sempit, sehingga untuk penelitian selanjutnya disarankan menggunakan derajat kesesuaian yang lebih tinggi dengan mempertimbangkan interval kepercayaan, subjek sampel serta kriteria sampel yang lebih beragam.

\section{KESIMPULAN}

Berdasarkan hasil penelitian yang telah dilakukan dapat disimpulkan bahwa terdapat kesesuaian hasil pemeriksaan kadar ureum pada penggunaan vacutainer serum separator dan vacutainer plain sebagai tabung penampung sampel, dengan rerata hasil pemeriksaan kadar ureum pada penggunaan vacutainer serum separator adalah 46,51 mg/dL Rerata hasil pemeriksaan kadar ureum pada penggunaan vacutainer plain adalah 46,16 mg/dL.Hasil pemeriksaan kadar ureum pada penggunaan vacutainer serum separator dan vacutainer plain sebagai tabung penampung sampel mempunyai derajat kesesuaian sedang dengan nilai ICC 0,745 . Sehingga untuk penelitian sejenis disarankan dapat dilakukan pada parameter lain dengan menggunakan derajat kesesuaian yang lebih tinggi dengan mempertimbangkan interval kepercayaan, subjek sampel serta kriteria sampel yang lebih beragam.

\section{DAFTAR PUSTAKA}

Arslan, F. D. et al. (2017) 'The local clinical validation of a new lithium heparin tube with a barrier: BD Vacutainer ${ }^{\circledR}$ Barricor LH Plasma tube', Biochemia Medica, 27(3). doi: 10.11613/BM.2017.030706.

Babakhani, B. et al. (2018) 'A New Formulation for Polymeric Separator Gels for Potential use in Blood Serum Separator Tubes', Progress in Rubber, Plastics and Recycling Technology, 34(1), pp. 35-53. doi: 10.1177/147776061803400103. 
Bowen, R. A. R. and Remaley, A. T. (2014) 'Interferences from blood collection tube components on clinical chemistry assays', Biochemia Medica, pp. 31-44. doi: 10.11613/BM.2014.006.

Bush, V. (2012) 'Effects of Preanalytical Variables in Therapeutic Drug Monitoring', in Therapeutic Drug Monitoring. Elsevier, pp. 31-48. doi: 10.1016/B978-0-12-3854674.00002-6.

Cuhadar, S. et al. (2012) 'Stability studies of common biochemical analytes in serum separator tubes with or without gel barrier subjected to various storage conditions', Biochemia Medica, pp. 202-214. doi: 10.11613/BM.2012.023.

Fatma, R. Z., Martsiningsih, M. A. and Suryanta, S. (2019) Perbedaan Kadar Ureum Pada Plasma Lithium Heparin Dengan Penggunaan Separator Tube Dan Vacutainer Pada Pasien Post Hemodialisa. Poltekkes Kemenkes Yogyakarta. Available at:

http://eprints.poltekkesjogja.ac.id/ 692/.

Kösem, A. et al. (2020) 'Comparison of some biochemical tests in different blood collection tubes in hemodialysis patients', Turkish Journal of Biochemistry, 45(1), pp. 26-36. doi: 10.1515/tjb-20180341.

Li, Z. et al. (2010) 'Evaluation of BD vacutainer $\mathrm{SST}^{\mathrm{TM}}$ II plus tubes for common tumor marker tests by Roche Diagnostics Modular E 170 analyzer', Journal of Clinical Laboratory Analysis, 24(6), pp. 418-421. doi: 10.1002/jcla.20422.
Lindh, W. Q. et al. (2013) Delmar's Comprehensive Medical Assisting: Administrative and Clinical Competencies. Cengage Learning. Available at: https://books.google.co.id/books?i $\mathrm{d}=$ oGaeq8Ftd3gC.

Narayanan, S. (2000) 'The Preanalytic Phase', American Journal of Clinical Pathology, 113(3), pp. 429-452. doi: 10.1309/C0NMQ7R0-LL2E-B3UY.

Nursalam (2016) Konsep Dan Penerapan Metodologi Penelitian Ilmu Keperawatan. Jakarta: Salemba Medika.

Sukorini (2010) Pemantapan Mutu Internal Laboratorium Klinik. Yogyakarta: Kanal Medika dan Alfamedia Citra.

Verdiansah (2016) 'Pemeriksaan Fungsi Ginjal', Cermin Dunia Kedokteran, 43(2), pp. 148-154.

Wei, Y. et al. (2010) 'The Feasibility of Using Lithium-Heparin Plasma From a Gel Separator Tube as a Substitute for Serum in Clinical Biochemical Tests', Laboratory Medicine, 41(4), pp. 215-219. doi:

10.1309/LMIXVAI70KS0UWQI.

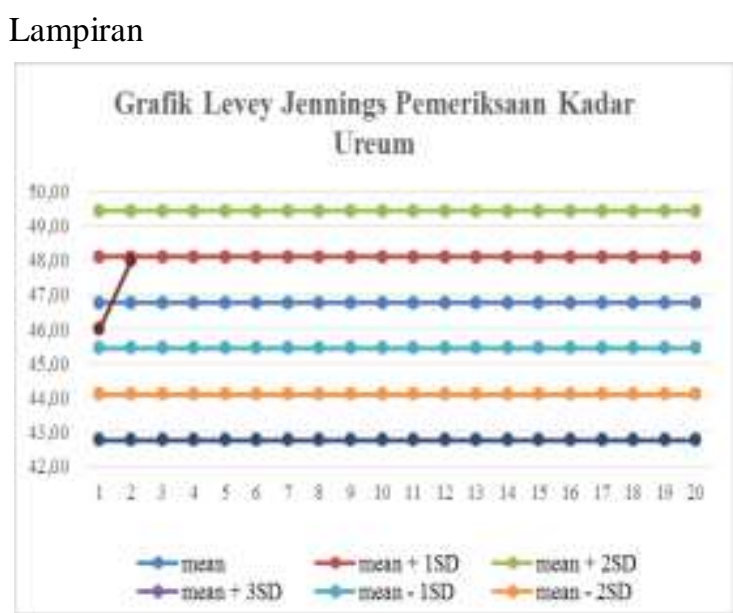

